\title{
Suscetibilidade a diabetes mellitus em cães obesos*
}

\author{
ANGELA PATRICIA MEDEIROS VEIGA
}

Félix Hilario Díaz González (Orientador - UFRGS)

Banca: Sonia Terezinha dos Anjos Lopes (UFSM), Kátia Padilha Barreto (UFSM), Luiz Carlos Rios Kucharski (UFRGS)

A obesidade vem aumentando progressivamente na população canina em decorrência de distúrbios endócrinos, alimentares e de manejo, o que leva ao aparecimento de doenças a ela relacionadas, sendo a Diabetes Mellitus a mais comum. Essa enfermidade ocorre devido a alterações na secreção ou sinalização da insulina em tecidos periféricos, gerando uma resistência periférica à insulina, o que pode levar à completa exaustão beta-pancreática, processo irreversível e incompatível com a vida. Pouco se sabe sobre a patogênese da resistência à insulina causada pela obesidade em cães. A proteína $\mathrm{C}$ reativa está relacionada à obesidade em humanos e roedores, mas não existem dados na literatura sobre a sua relação com a obesidade e resistência à insulina em cães. O transportador de glicose GLUT4 tem importante função na entrada de glicose nas células adiposas e musculares. A alteração na expressão dessa proteína já foi associada à obesidade em várias espécies, incluindo cães, porém não se sabe se essa alteração está relacionada à resistência à insulina. O objetivo deste trabalho foi elucidar alguns aspectos bioquímicos e moleculares que cercam a resistência à insulina induzida pela obesidade em cães e, com isso, gerar subsídios para a prevenção da diabetes mellitus na espécie canina. Para tanto, foram realizados três experimentos, onde os dois primeiros tentaram elucidar aspectos bioquímicos da obesidade (efeito sobre os níveis de proteína C-reativa) e resistência à insulina (efeito sobre os níveis de fructosamina), e o último tentou avaliar aspectos moleculares em tecido adiposo e muscular (efeito sobre a expressão de GLUT4). Os resultados mostraram que a proteína C-reativa não se altera com a obesidade canina, e que a fructosamina altera-se com o desenvolvimento da resistência à insulina em cães. Uma modificação no padrão expressão da proteína GLUT4 entre os tecidos muscular e adiposo foi observada na presença da resistência à insulina, e uma alteração na translocação foi verificada nos dois tecidos, causada pela obesidade. Com base nos resultados obtidos, pode-se concluir que a patogênese da resistência à insulina, causada pela obesidade, não é similar a outras espécies, e deve ser prevenida com medidas distintas. O presente estudo também gerou informações que podem auxiliar no diagnóstico e prevenção da resistência à insulina e diabetes mellitus na espécie canina.

Descritores: metabolismo, caninos, pâncreas, insulina.

*Tese de Doutorado n.85 (Especialidade: Morfologia, Cirurgia e Patologia Animal). 90f. Programa de Pós-graduação em Ciências Veterinárias [www.ufrgs.br/ppgcv], Faculdade de Veterinária, Universidade Federal do Rio Grande do Sul (UFRGS), Porto Alegre/RS. CORRESPONDÊNCIA: A.P.M. Veiga [angelavet@terra.com.br]. 


\title{
Susceptibility to diabetes mellitus in obese dogs**
}

\author{
ANGELA PATRICIA MEDEIROS VEIGA
}

Félix Hilario Díaz González (Adviser - UFRGS)

Committee: Sonia Terezinha dos Anjos Lopes (UFSM), Kátia Padilha Barreto (UFSM), Luiz Carlos Rios Kucharski (UFRGS)

Obesity has been progressively increasing in canine population due to endocrine, nutritional and management disturbances, what leads to the appearance of related diseases, being Diabetes Mellitus the most common. This illness occurs because of insulin secretion or signaling alterations, generating a peripheral insulin resistance, what can lead to a complete beta-pancreatic exhaustion that is considered an irreversible and life-incompatible process. Little is known about pathogenesis of insulin resistance caused by obesity in dogs. C-reactive protein is related to obesity in human and rodent species, but there is no data in the literature about its relation with obesity and insulin resistance in dogs. GLUT4 glucose transporter has an important role on adipose and muscular cells glucose uptake. Alterations on GLUT4 protein expression have been established in obesity in some species including dogs, but there is no knowledge about this mechanism in insulin resistance in canine species. The aim of this work was to elucidate some biochemical and molecular issues surrounding obesity induced insulin resistance in dogs and thus generate information leading to prevention of diabetes mellitus in canine species. To achieve that, three experiments were accomplished, where the first two tried to elucidate biochemical aspects of obesity (effect on C-reactive protein levels) and insulin resistance (effect on fructosamine levels), and the third attempted to evaluate molecular aspects in fat and muscular tissues (effect on GLUT4 expression). Results showed that C-reactive protein levels do not alter with canine obesity, and that fructosamine levels change with the onset of insulin resistance. A modification on GLUT4 protein expression pattern between adipose and muscular tissues was observed in the presence of insulin resistance and a translocational alteration was detected in both tissues, caused by obesity. Based on the obtained results it can be postulated that the pathogenesis of insulin resistance caused by obesity differs from other species, and must be prevented with distinct measures. Furthermore, the present study generated information that can help on diagnosis and prevention of insulin resistance and diabetes mellitus in canine species.

Key words: metabolism, canine, pancreas, insulin.

Presented: 18 December 2007

\footnotetext{
**Doctoral Dissertation \#85 (Field: Morphology, Surgery and Animal Pathology). 90p. Graduate Program in Veterinary Sciences[www.ufrgs.br/ ppgcv], Faculdade de Veterinária, Universidade Federal do Rio Grande do Sul (UFRGS), Porto Alegre/Brazil. CORRESPONDENCE: A.P.M. Veiga [angelavet@terra.com.br].
} 